\title{
ANALISIS EFISIENSI ALOKASI PENGGUNAAN FAKTOR PRODUKSI PADA USAHATANI TOMAT DI KECAMATAN KAPONTORI KABUPATEN BUTON
}

\author{
Gusmin Sarif Amane ${ }^{1)}$, Bahari' ${ }^{2)}$, La Ode Geo ${ }^{3)}$ \\ ${ }^{1)}$ Pascasarjana Universitas Halu Oleo \\ ${ }^{1)}$ Email: syarif.ajha18@gmail.com \\ ${ }^{2) \& 3)}$ Tenaga Pengajar Pascasarjana Universitas Halu Oleo \\ ${ }^{2)}$ Email: bahari.abdulah@yahoo.com \\ ${ }^{3)}$ Email: geolaode@yahoo.co.id
}

Naskah diterima: 12 April 2019

Naskah direvisi: 19 April 2019

Disetujui diterbitkan: 26 April 2019

\begin{abstract}
This study aims to analyze the factors that influence production and analyze the efficiency of allocation of the use of production factors on tomato farming conducted in Kapontori District, Buton Regency. Data collection was conducted in January-April 2019 with the survey method. A total of 67 tomato farmers were selected as samples using the simple random sampling method. Data were analyzed using multiple nonlinear regression with Cobb-Douglas production function followed by calculation of price efficiency. The results showed that the area of land, seeds, and fertilizers were factors of production which had a significant effect on tomato production. Tomato farming is on an increasing return to scale scale where increasing use of factors in the production of land, seeds, fertilizers, pesticides and labor simultaneously leads to a greater increase in tomato production. Production factor allocation efficiency analysis shows that the use of production factors in land area is not efficient so it needs to be added, the use of seed production factors is not efficient so it needs to be added, and the use of fertilizer production factors is inefficient so it needs to be reduced.
\end{abstract}

Keywords: efficiency, production factors, tomatoes, production

Intisari: Studi ini bertujuan untuk menganalisis faktor-faktor yang mempengaruhi produksi dan menganalisis efisiensi alokasi penggunaan faktor-faktor produksi pada usahatani tomat dilakukan di Kecamatan Kapontori Kabupaten Buton. Pengumpulan data dilakukan pada bulan Januari-April 2019 dengan metode survei. Sebanyak 67 petani tomat dipilih sebagai sampel dengan menggunakan metode simple random sampling. Data dianalisis menggunakan regresi nonlinier berganda dengan fungsi produksi Cobb-Douglas dilanjutkan dengan perhitungan efisiensi harga. Hasil studi menunjukkan bahwa luas lahan, benih, dan pupuk merupakan faktor produksi yang berpengaruh signifikan terhadap produksi tomat. Usahatani tomat berada pada skala usaha meningkat (increasing return to scale) di mana peningkatan penggunaan faktor produksi luas lahan, benih, pupuk, pestisida dan tenaga kerja secara bersamaan menyebabkan peningkatan produksi tomat yang lebih besar. Analisis efisiensi alokasi faktor produksi menunjukkan bahwa penggunaan faktor produksi luas lahan belum efisien sehingga perlu penambahan, penggunaan faktor produksi benih belum efisien sehingga perlu penambahan, dan penggunaan faktor produksi pupuk tidak efisien sehingga perlu dikurangi.

Kata kunci : efisiensi, faktor produksi, tomat, produksi 


\section{PENDAHULUAN}

Penggunaan faktor produksi merupakan salah satu kunci utama dalam pembangunan pertanian. Penggunaan faktor produksi yang tidak tepat dan tidak efisien akan menyebabkan penurunan produksi yang berakibat pada rendahnya pendapatan usahatani (Yuliana et.al., 2017). Pengelolaan penggunaan faktor produksi yang tepat dan efisien dapat meningkatkan produksi dan menjaga keberlanjutan usahatani tomat. Upaya peningkatan produksi tanaman pangan melalui efisiensi produksi menjadi salah satu pilihan yang tepat. Dengan efisiensi, petani dapat menggunakan input produksi sesuai dengan ketentuan untuk mendapat produksi yang optimal (Agustin et.al., 2018). Pada umumnya petani menggunakan input atau faktor produksi tidak optimal, sehingga pemeliharaan aktivitas usahatani tidak memadai (Muin, et.al., 2017). Padahal, penggunaan faktor produksi seperti luas lahan, benih, pupuk, pestisida dan tenaga kerja secara tepat dan efisien akan memberikan keuntungan bagi petani.

Efisiensi faktor produksi meliputi efisiensi teknis, efisiensi harga dan efisiensi ekonomi. Efisiensi ekonomi merupakan hasil kali antara seluruh efisiensi harga/alokatif dari seluruh faktor input. Usahatani tomat dengan menggunakan faktor produksi secara efisien maka akan meningkatkan keuntungan yang maksimum (Ningsi et.al., 2015). Petani diharapkan memiliki kemampuan dan pengetahuan mengenai pengelolaan tingkat penggunaan faktor produksi secara optimal agar dapat meningkatkan keuntungan dalam kegiatan usahatani terutama untuk komoditas tomat

Kecamatan Kapontori merupakan salah satu kecamatan penghasil tomat tertinggi di Kabupaten Buton. Namun, produksi tomat dari tahun 2013 sampai tahun 2017 mengalami fluktuaktif (BPS Buton, 2018). Produksi yang fluktuatif dapat disebabkan oleh beberapa hal meliputi faktor lingkungan, teknik budidaya yang kurang baik serta penggunaan faktor produksi yang tidak efektif maupun efisien. Petani di Kecamatan Kapontori termasuk petani aktif dalam kegiatan usahatani tomat, hal tersebut dapat dilihat adanya gapoktan di Kecamatan Kapontori. Dengan adanya gapoktan di Kecamatan Kapontori dapat mempermudah akses petani dalam penyediaan sarana produksi. Namun kondisi ketersediaan sarana produksi yang ada di Kecamatan Kapontori masih terbatas, sehingga kebutuhan untuk benih unggul, pupuk berimbang dan pestisida belum maksimal serta kurang efisiennya alokasi penggunaan faktor produksi. Hal tersebut yang membuat produksi tomat di Kematan Kapontori mengalami fluktuatif.

Penggunaan faktor produksi merupakan salah satu kunci utama dalam keberhasilan dalam berusahatani. Penggunaan faktor produksi yang tidak tepat dan tidak efisien akan menyebabkan penurunan produksi yang berakibat pada rendahnya pendapatan usahatani (Yuliana et.al., 2017). Pengelolaan penggunaan faktor produksi yang tepat dan efisien dapat meningkatkan produksi dan menjaga keberlanjutan usahatani tomat. Upaya peningkatan produksi tanaman pangan melalui efisiensi produksi menjadi salah satu pilihan yang tepat. Dengan efisiensi, petani dapat menggunakan input produksi sesuai dengan ketentuan untuk mendapat produksi yang optimal (Agustin et.al., 2018). Pada umumnya petani menggunakan input atau faktor produksi tidak optimal, sehingga pemeliharaan aktivitas usahatani tidak memadai (Muin et.al., 2017). Padahal, penggunaan faktor produksi seperti luas lahan, benih, pupuk, pestisida dan tenaga kerja secara tepat dan efisien akan memberikan keuntungan bagi petani.

Efisiensi faktor produksi meliputi efisiensi teknis, efisiensi harga dan efisiensi ekonomi. Efisiensi harga tercapai bila nilai produk marginal (NPM) sama dengan biaya korbanan marginal (BKM). Usahatani tomat dengan menggunakan faktor produksi secara efisien maka akan meningkatkan keuntungan yang maksimum (Ningsi et.al., 2015). Petani diharapkan memiliki kemampuan dan pengetahuan mengenai pengelolaan tingkat penggunaan faktor produksi secara optimal agar dapat meningkatkan keuntungan dalam kegiatan usahatani terutama untuk komoditas tomat.

Tujuan dari studi ini adalah menganalisis faktor-faktor yang mempengaruhi produksi usahatani tomat dan menganalisis tingkat efisiensi alokasi penggunaan faktor-faktor produksi usahatani tomat di Kecamatan Kapontori, Kabupaten Buton. Hasil studi dapat dimanfaatkan petani sebagai bahan pertimbangan dalam penggunaan faktor produksi supaya lebih efisien. 


\section{METODE STUDI}

Studi dilaksanakan di Kecamatan Kapontori Kabupaten Buton yang berlangsung selama bulan Januari-April Tahun 2019. Pemilihan lokasi studi ditentukan secara sengaja (purposive) dengan pertimbangan bahwa Kecamatan Kapontori Kabupaten Buton merupakan salah satu daerah yang potensial untuk pengembangan komoditas tomat.

Dari kecamatan terpilih, ditentukan 2 (dua) desa yang memiliki lahan pertanian terluas dan keaktifan petani serta kelompok tani dalam kegiatan usahatani tinggi, yaitu Desa Wakuli 34 petani dan Desa Bukit Asri 33 petani. Penentuan sampel studi di masing-masing desa dilakukan dengan menggunakan teknik Simple Random Sampling (sampel acak sederhana).

Data yang telah dikumpulkan dianalisis menggunakan fungsi produksi non linier model CobbDouglas, dilanjutkan dengan analisis efisiensi harga.Analisis fungsi produksi non linier model CobbDouglas dapat menjelaskan pengaruh penggunaan faktor produksi meliputi luas lahan, benih, pupuk, pestisida dan tenaga kerja terhadap jumlah produksi usahatani tomat (Y) dalam satu kali proses produksi dengan model persamaan sebagai berikut (Muin, et.al., 2017):

$$
\mathrm{Y}=\mathrm{b}_{0} \mathrm{X}_{1}^{\mathrm{b} 1} \cdot \mathrm{X}_{2}^{\mathrm{b} 2} \cdot \mathrm{X}_{3}{ }^{\mathrm{b} 3} \cdot \mathrm{X}_{4}{ }^{\mathrm{b} 4} \cdot \mathrm{X}_{5}{ }^{\mathrm{b} 5} \cdot \mu
$$

Untuk memudahkan perhitungan maka persamaan tersebut kemudian diubah dalam bentuk persamaan linier sebagai berikut:

$$
\begin{aligned}
& \ln Y=b_{0}+b_{1} \ln X_{1}+b_{2} \ln X_{2}+b_{3} \ln X_{3}+b_{4} \ln X_{4}+b_{5} \ln X_{5} .+\ln \mu \\
& \text { Keterangan: } \\
& \mathrm{Y}=\text { produksi tomat }(\mathrm{kg} / \mathrm{ha}) \\
& \mathrm{b}_{0} \quad=\text { konstanta } \\
& \mathrm{b}_{1} \ldots \mathrm{b}_{5}=\text { koefisien regresi varibael } \mathrm{X}_{1} \ldots \mathrm{X}_{5} \\
& \mathrm{X}_{1} \quad \text { = luas lahan (ha) } \\
& \mathrm{X}_{2} \quad=\text { jumlah benih }(\mathrm{gr} / \mathrm{ha}) \\
& \mathrm{X}_{3} \quad=\text { jumlah pupuk }(\mathrm{kg} / \mathrm{ha}) \\
& \mathrm{X}_{4} \quad=\text { jumlah pestisida (liter/ha) } \\
& \mathrm{X}_{5}=\text { jumlah tenaga kerja }(\mathrm{HOK} / \mathrm{ha}) \\
& \mathrm{u} \quad=\text { variable pengganggu/eror }
\end{aligned}
$$

Untuk menguji apakah faktor produksi luas lahan, benih, pupuk pestisida, dan tenaga kerja secara serempak berpengaruh nyata terhadap produksi dilakukan menggunakan Uji $\mathrm{F}$ pada tingkat kepercayaan $95 \%(\alpha=0,05)$ dengan kriteria sebagai berikut (Joan et.al., 2018):

- Jika nilai signifikansi $\mathrm{F}_{\text {-hitung }}>\alpha=0,05$, maka secara bersama-sama variabel bebas (Xi) tidak berpengaruh nyata variabel terikat $(\mathrm{Y})$.

- Jika nilai signifikansi $\mathrm{F}_{\text {-hitung }}<\alpha=0,05$, maka secara bersama-sama variabel bebas (Xi) berpengaruh nyata terhadap variabel terikat (Y).

Selanjutnya untuk menguji pengaruh masing-masing faktor produksi luas lahan, benih, pupuk, pestisida, dan tenaga kerja secara parsial terhadap produksi digunakan Uji Parsial (Uji t) dengan kriteria sebagai berikut:

- Jika nilai signifikansi $\mathrm{t}_{\text {-hitung }}>\alpha=0,05$, maka secara parsial variabel bebas (Xi) tidak berpengaruh nyata terhadap variabel terikat $(\mathrm{Y})$.

- Jika nilai signifikansi t-hitung $<\alpha=0,05$, maka secara parsial variabel bebas (X) berpengaruh nyata terhadap variabel terikat (Y).

Analisis efisiensi harga digunakan untuk menganalisis tingkat efisiensi alokasi penggunaan faktor produksi usahatani tomat. Efisiensi harga tercapai bila nilai produk marginal (NPM) sama dengan biaya korbanan marginal (BKM) sehingga dapat dirumuskan sebagai berikut (Yuliana et.al., 2017). 


$$
\frac{N P M x i}{B K M x i}=\frac{B x i \cdot \frac{Y}{X i} \cdot P y}{P x i} \text { atau } \frac{M P P \cdot P y}{P x i}=1
$$

Kriteria pengujian sebagai berikut:

a. Penggunaan faktor produksi tidak efisien jika

$$
\frac{M P P . P y}{P x i}<1
$$

b. Penggunaan faktor produksi sudah efisien jika

$$
\frac{M P P . P y}{P x i}=1
$$

c. Penggunaan faktor produksi belum efisien jika

$$
\frac{M P P . P y}{P x i}>1
$$

\section{HASIL DAN PEMBAHASAN}

\section{Alokasi Penggunaan Faktor Produksi}

Faktor produksi yang digunakan dalam studi ini adalah luas lahan, penggunaan benih, penggunaan pupuk (Urea, pupuk SP-36, NPK Phonska, NPK Mutiara), pestisida dan tenaga kerja. Alokasi penggunaan faktor produksi pada usahatani tomat dapat dilihat pada Tabel 1.

Tabel 1. Alokasi Penggunaan Faktor Produksi Tomat di Kecamatan Kapontori Kabupaten Buton Tahun 2019

\begin{tabular}{lllr}
\hline No. & Faktor Produksi & Satuan & Rata-rata \\
\hline 1. & Luas lahan & $\mathrm{Ha}$ & 0,63 \\
2. & Benih & $\mathrm{gr} / \mathrm{ha}$ & 77,31 \\
3. & Pupuk & $\mathrm{kg} / \mathrm{ha}$ & 207,24 \\
4. & Pestisida & liter/ha & 1,98 \\
5. & Tenaga Kerja & HOK/ha & 72,68 \\
\hline
\end{tabular}

Berdasarkan Tabel 1 dapat disampaikan bahwa rata-rata penggunaan faktor produksi benih sebanyak 77,31 gr/ha dengan luas lahan 0,63 ha. Penggunaan benih relatif sedikit dan tidak sesuai anjuran yakni 100-150 gr/ha (Yuliana et.al., 2017). Rata-rata penggunaan pupuk (Urea, SP-36, NPK Phonska, NPK Mutiara) sebanyak 207,24 kg/ha dengan luas lahan 0,63. Rekomendasi penggunaan pupuk Urea, SP-36, NPK Phonska, NPK Mutiara adalah pupuk Urea 100-150 kg/ha, SP-36 dan NPK 300-400 kg/ha (Azri, 2018). Penggunaan pupuk Urea sebaiknya dikurangi karena penggunaan pupuk Urea yang berlebihan akan mengakibatkan tanah menjadi masam, sehingga penyerapan unsur hara akan menghambat dan biaya usahatani menjadi lebih banyak. Hal tersebut seseuai dengan pendapat Triyono et.al., (2013) bahwa efisiensi penggunaan pupuk $\mathrm{N}$ dilakukan dengan pemberian sesuai dengan rekomendasi. Pupuk Urea yang berlebihan akan menghambat penyerapan unsur hara dan tanaman akan mudah terserang hama dan penyakit.

Rata-rata penggunaan pestisida per satu kali produksi sebanyak 1,98 liter/ha dengan luas lahan 0,63 ha. Serangan hama dan penyakit yang biasa terjadi di Kecamatan Kapontori adalah kutu daun hijau, lalat buah, layu fusarium dan busuk buah. Penggunaan pestisida harus disesuaikan dengan hama dan penyakit yang ada di lahan agar tidak merugikan petani. Hal tersebut sesuai dengan pendapat Insani et.al., (2018) yang menyatakan bahwa pestisida sangat dibutuhkan petani untuk mencengah serta membasmi hama dan penyakit tanaman, tetapi dapat merugikan petani jika pemakaian baik dari cara 
maupun komposisi yang diaplikasikan ke tanaman tidak sesuai. Rata-rata Tenaga kerja yang digunakan per satu kali produksi sebanyak 72,68 HOK/ha.

\section{Analisis Fungsi Produksi Cobb-Douglas}

Analisis fungsi produksi Cobb-Douglass digunakan untuk mengetahui hubungan antara faktor produksi dengan jumlah produksi. Hubungan tersebut dapat diketahui dengan melihat koefisien regresi dari regresi linier berganda dengan mengubah model fungsi produksi Cobb-Douglass ke dalam bentuk logaritma natural. Berikut merupakan hasil analisis data untuk mengestimasi parameter model persamaan linier:

$\ln \mathrm{Y}=4,979+0,888 \ln \mathrm{X}_{1}+0,830 \ln \mathrm{X}_{2}+0,043 \ln \mathrm{X}_{3}+0,001 \ln \mathrm{X}_{4}+0,023 \ln \mathrm{X}_{5}+\ln \mathrm{e}$

Kemudian persamaan linear tersebut dirubah kembali dalam bentuk persamaan nonlinear dengan model fungsi produksi Cobb-Douglass menjadi:

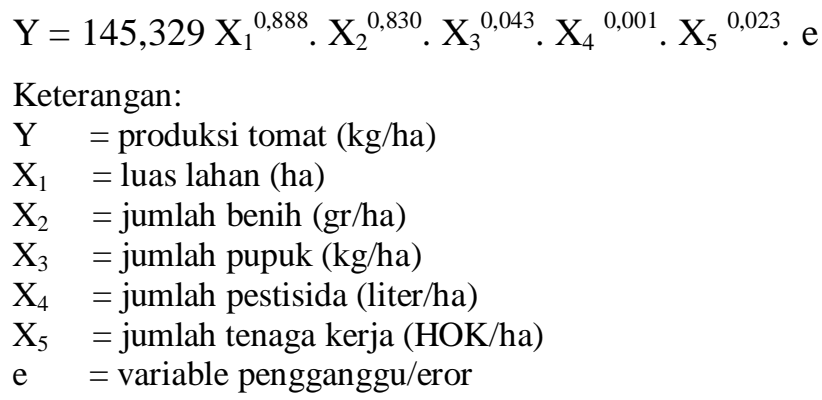

Tabel 2. Hasil Analisis Faktor Produksi Usahatani Tomat di Kecamatan Kapontori Kabupaten Buton Tahun 2019

\begin{tabular}{llccc}
\hline No. & Variabel & Koefisien Regresi (b) & t-hitung & Signifikansi \\
\hline 1. & (Constant) & 4,979 & & \\
2. & Luas lahan $\left(\mathrm{X}_{1}\right)$ & 0,888 & 18,995 & $0,000^{* *}$ \\
3. & Benih $\left(\mathrm{X}_{2}\right)$ & 0,830 & 13,270 & $0,000^{* *}$ \\
4. & Pupuk $\left(\mathrm{X}_{3}\right)$ & 0,043 & 2,765 & $0,008^{* * *}$ \\
5. & Pestisida $\left(\mathrm{X}_{4}\right)$ & 0,001 & 0,083 & $0,934^{\text {tn }}$ \\
6. & Tenaga Kerja $\left(\mathrm{X}_{5}\right)$ & 0,023 & 0,538 & $0,593^{\text {th }}$ \\
7. & R-Square & 0,949 & & 0,000 \\
8. & F-hitung & 226,226 & & 0,000 \\
\hline
\end{tabular}

Keterangan: $* *=$ berpengaruh nyata pada taraf $95 \%(\alpha=0,05)$

$\mathrm{tn}=$ tidak berpengaruh nyata pada taraf $95 \%(\alpha=0,05)$

Berdasarkan hasil analisis data diperoleh nilai $\mathrm{F}_{\text {hitung }}$ sebesar 226,226 dengan tingkat signifikansi pada $\alpha=0,05$ (tingkat kesalahan $5 \%$ atau tingkat kepercayaan 95\%) adalah sebesar 0,000. Nilai signifikansi tersebut lebih kecil dari nilai $\alpha=0,05$, artinya bahwa semua faktor produksi yang terdiri atas luas lahan benih, pupuk, pestisida, dan tenaga kerja secara serempak berpengaruh nyata terhadap produksi tomat.

Nilai koefisien determinasi $\left(\mathrm{R}^{2}\right)$ adalah sebesar 0,949 yang berarti bahwa sebesar 94,9\% variasi produksi usahatani tomat dapat dijelaskan oleh variabel bebas. Dengan kata lain bahwa besarnya kontribusi semua variabel bebas terhadap produksi usahatani tomat sebesar 94,9\%, sedangkan sisanya sebesar 5,1\% ditentukan oleh keragaman variabel lain yang tidak dimasukan dalam model analisis.

Analisis uji $\mathrm{t}$ diperoleh hasil bahwa faktor produksi yang digunakan dalam usahatani tomat, yaitu luas lahan, benih dan pupuk merupakan faktor produksi yang berpengaruh nyata terhadap produksi 
tomat. Hal tersebut dilihat dari nilai signifikansi dari faktor produksi tersebut lebih kecil dari $\alpha=0,05$. Faktor produksi pestisida dan tenaga kerja berpengaruh tidak nyata terhadap produksi tomat karena nilai signifikansi $>0,05$.

Tabel 2 menunjukkan bahwa signifikansi variabel luas lahan adalah 0,000 lebih kecil dari $\alpha=$ 0,05 . Hal ini berarti variabel luas lahan berpengaruh nyata terhadap produksi tomat. Koefisien regresi faktor produksi luas lahan $\left(\mathrm{b}_{1}\right)$ sebesar 0,888 yang berarti peningkatan penggunaan luas lahan sebesar $1 \%$ maka akan meningkatkan produksi atau produktivitas sebesar $0,888 \%$. Atau dengan kata lain, di lokasi studi semakin luas lahan yang dikelola petani maka usahatani tomat yang dilakukan semakin efisien. Hal tersebut sesuai dengan pendapat Mamondol (2017) yang menyatakan bahwa luas lahan pertanian akan mempengaruhi skala usaha dan efisiensi tidaknya suatu usaha pertanian.

Faktor produksi benih berpengaruh nyata terhadap produksi karena penggunaan benih tomat yang unggul akan meningkatkan kualitas dan kuantitas produksi. Koefisien regresi faktor produksi benih $\left(\mathrm{b}_{2}\right)$ sebesar 0,830 yang berarti penambahan penggunaan benih sebesar $1 \%$ maka akan meningkatkan produksi sebesar $0,830 \%$. Hal tersebut dikarenakan rata-rata alokasi penggunaan benih tomat di lokasi studi belum sesuai anjuran. Selain itu, sesuai dengan pendapat Jamalludin (2018) yang menyatakan bahwa penggunaan benih unggul akan berpengaruh terhadap besaran produksi/hasil tomat per hektar, ketahanan terhadap penyakit, rasa dan daging buah, umur tanaman serta panen tanaman tomat.

Faktor produksi pupuk berpengaruh nyata terhadap produksi tomat, sehingga penambahan penggunaan pupuk sebesar $1 \%$ maka akan meningkatkan produksi sebesar 0,043\%. Kandungan unsur hara pupuk N,P,K meliputi N,P, dan K merupakan unsur hara makro yang dibutuhkan tanaman tomat. Pupuk NPK mudah larut dalam air sehingga unsur hara dapat segera diserap dan digunakan oleh tanaman untuk menghasilkan produksi yang optimal. Hal tersebut sesuai dengan pendapat Azri (2018) yang menyatakan bahwa pupuk NPK merupakan salah satu pupuk anorganik yang dapat digunakan dalam meningkatkan ketersediaan unsur hara makro (N,P, dan K) dan dapat menggantikan pupuk tunggal seperti pupuk tunggal seperti Urea, SP-36, dan KCl.

Signifikansi variabel pestisida adalah sebesar 0,934 lebih besar dari $\alpha=0,05$. Hal ini berarti variabel pestisida berpengaruh tidak nyata terhadap produksi tomat. Pestisida merupakan salah satu teknologi modern karena mempunyai peranan penting dalam mempertahankan produksi. Hal ini terbukti di beberapa Negara sedang berkembang produksi pertanian melimpah, namun apabila pestisida dalam pengelolaannya tidak sesuai dan berlebihan maka dapat menimbulkan dampak negatif terhadap lingkungan, kesehatan, dan produksi yang dihasilkan (Insani et.al., 2018). Hal tersebut sesuai dengan pendapat (Zulkarnain, 2010) yang menyatakan bahwa dampak negatif yang ditimbulkan dari penggunaan pestisida yang tidak baik dan berlebihan dapat mencemari lingkungan dan dapat mengganggu kesehatan manusia serta dapat menurunkan produksi tanaman.

Hasil analisis juga menunjukkan bahwa signifikansi variabel tenaga kerja adalah 0,593 lebih besar dari $\alpha=0,05$. Hal ini berarti variabel tenaga kerja berpengaruh tidak nyata terhadap produksi tomat. Penggunaan tenaga kerja berpengaruh tidak nyata terhadap produksi tomat hal ini disebabkan karena penggunaan tenaga kerja pada budidaya tomat lebih banyak digunakan pada awal dan akhir produksi saja, sedangkan kegiatan pemeliharaan kurang dilakukan sehingga berpengaruh tidak nyata dalam peningkatan produksi.

Return to scale (RTS) digunakan untuk mengetahui apakah suatu usaha yang diteliti mengikuti kaidah increasing, constant atau decreasing return to scale (Mamondol, 2017). Untuk menjelaskan hal ini digunakan besaran elastisitas $b_{1}, b_{2}, b_{3}, b_{4}, b_{5} \ldots$ bn yang mempunyai kemungkinan lebih dari satu, sama dengan satu atau lebih kecil dari satu. Hasil regresi pada Tabel 2 menunjukkan bahwa jumlah beta atau koefisien regresi dari kelima variabel adalah 1,785. Angka ini mengindikasikan bahwa usahatani tomat yang dijalankan di Kecamatan Kapontori Kabupaten Buton berada pada kondisi increasing return to scale karena $\mathrm{b}_{1}+\mathrm{b}_{2}+\mathrm{b}_{3}+\mathrm{b}_{4}+\mathrm{b}_{5}=1,785$ lebih besar dari satu, di mana tambahan output lebih besar dari pada tambahan input. Jadi apabila penggunaan faktor produksi luas lahan, benih, pupuk, pestisida dan tenaga kerja ditingkatkan bersama-sama secara proporsional sebesar $1 \%$ 
maka produksi tomat akan meningkat sebesar 1,785\%. Sebaliknya jika kelima faktor produksi dikurangi sebesar $1 \%$ secara bersama-sama maka produksi tomat akan menurun sebesar 1,785\%.

\section{Efisiensi Alokasi Penggunaan Faktor Produksi}

Petani perlu mengetahui hasil analisis efisiensi harga untuk membantu dalam pengalokasian penggunaan faktor produksi, sehingga tidak terjadi pemborosan karena berpengaruh terhadap hasil produksi dan keuntungan usahatani. Efisiensi harga atau alokasi penggunaan faktor produksi efisien jika nilai produk marginal dari setiap faktor produksi sama dengan harga setiap faktor produksi yang digunakan (Tahir et.al., 2010).

Efisiensi harga dapat diketahui dari perhitungan produk marginal, harga input dan harga produk. Perhitungan nilai efisiensi dilakukan setiap faktor produksi dan tidak secara bersamaan. Nilai input (X), harga input (Px), marginal produk (MPP), produksi (Y), harga tomat per kg (Py) dan hasil perhitungan efisiensi harga disajikan pada Tabel 3.

Tabel 3. Perhitungan Efisiensi Harga Usahatani Tomat di Kecamatan Kapontori Kabupaten Buton Tahun 2019

\begin{tabular}{lcrrrc}
\hline Faktor Produksi & (b) & \multicolumn{1}{c}{ X } & Px (Rp) & MPP & Efisiensi Harga \\
\hline Luas lahan (ha) & 0,888 & 0,63 & 100,000 & 6,78 & 4,74 \\
Benih (gr) & 0,830 & 77,31 & 185,000 & 51,65 & 1,95 \\
Pupuk (kg) & 0,043 & 207,24 & 115,000 & 0,99 & 0,60 \\
Produksi (Y=4,811 kg) & & & & & \\
Harga tomat/kg (Py = Rp 7,000) & & & & & \\
\hline
\end{tabular}

Tabel 3 diketahui bahwa nilai efisiensi harga penggunaan faktor produksi luas lahan sebesar 4,74 berarti $>1$ maka penggunaan faktor produksi luas lahan usahatani tomat secara ekonomi belum efisien sehingga pengunaan luas lahan perlu penambahan. Nilai efisiensi harga penggunaan faktor produksi benih sebesar 1,95 berarti > 1 maka penggunaan faktor produksi benih belum efisien sehingga perlu penambahan. Rata-rata penggunaan faktor produksi benih per proses produksi sebesar 77,31 gr/ha, sedangkan rekomendasi penggunaan benih tomat 100-150 gr/ha (Jamalludin, 2018) sehingga perlu penambahan.

Nilai efisiensi faktor produksi pupuk sebesar 0,60 berarti $<1$ maka penggunaan faktor produksi pupuk usahatani tomat secara ekonomi tidak efisien sehingga perlu pengurangan input. Rata-rata penggunaan pupuk dalam satu tahun sebesar 207,24 kg/ha. Penggunaan pupuk harus dilakukan dengan tepat dan sesuai dengan kebutuhan untuk memperoleh hasil yang maksimal. Hal tersebut sesuai dengan pendapat Nahak et.al., (2018) yang menyatakan bahwa penggunaan pupuk harus diberikan sesuai dengan kebutuhan. Pengaruh pupuk sangat penting dalam pertumbuhan dan produksi tanaman. Semakin tepat kandungan unsur hara untuk tanaman maka pertumbuhan dan produksi akan semakin baik. Kebalikannya jika kandungan hara tidak dapat menyuplai kebutuhan hara tanaman maka akan memperhambat dan produksi akan menurun (Yuliana et.al., 2017).

\section{KESIMPULAN}

Dari sejumlah variabel yang dianalisis dapat disimpulkan bahwa penggunaan faktor produksi luas lahan, benih dan pupuk berpengaruh nyata terhadap produksi tomat sedangkan penggunaan faktor produksi lain seperti pestisida dan tenaga kerja berpengaruh tidak nyata terhadap produksi. Di antara faktor-faktor produksi yang berpengaruh tidak nyata terhadap produksi, pestisida merupakan variabel yang nilai signifikasinya paling besar. Artinya, pada usahatani tomat di lokasi studi, pestisida merupakan faktor produksi yang tidak mempunyai pengaruh langsung terhadap produksi. 
Analisis efisiensi harga menunjukkan bahwa penggunaan faktor produksi luas lahan dan benih belum efisien. Artinya, petani harus meningkatkan penggunaan benih sesuai dengan yang direkomendasikan. Sementara itu, penggunaan pupuk tidak efisien, artinya petani harus mengurangi jumlah penggunaan pupuk.

\section{DAFTAR PUSTAKA}

Insani, A.Y., Ancah C.N Marchianti, S.Surya Wahyudi. 2018. Perbedaan Efek Paparan Pestisida Kimia dan Organik terhadap Kadar Glutation (GSH) Plasma pada Petani Padi. Jurnal Kesehatan Lingkungan Indonesia. Vol. 17 (2): 63 - 67.

Joan, A.P., Iwan N, Suwarta. 2018. Analisis Fungsi Produktivitas Dan Fungsi Pendapatan Usahatani Jagung Arjuna Di Desa Mulyo Agung Kecamatan Dau Kabupaten Malang. Jurnal Ilmu-Ilmu Pertanian "AGRIKA". Vol. 12 (1): 83 - 92.

Azri. 2018. Respon Pupuk Organik Dan Pupuk Anorganik Terhadap Pertumbuhan Dan Produktivitas Buah Naga. Jurnal Pertanian Agros. Vol. 20 (1): 1 - 9.

BPS. 2018. Survei pertanian: Produksi Tanaman Sayuran di Sulawesi Tenggara. BPS Sulawesi Tenggara.

Nahak, B., Antonius S.S Ndiwa, M. Kasim. 2018. Pengaruh Kombinasi Pupuk npk Mutiara dan Pupuk Kandang (Kotoran Sapi) Terhadap Pertumbuhan dan Hasil Tanaman Tomat. Jurnal Agrisa. Vol. 7 (2): 258 - 267.

Agustin, H.U., Wahyu H. Rianto, H. Kusuma. 2018. Analisis Pengaruh Modal Dan Tenaga Kerja Terhadap Efisiensi produksi Genteng Di Desa Sukorejo Kecamatan Gandusari Kabupaten Trenggalek. Jurnal Ilmu Ekonomi. Vol. 2 (2): $194-205$.

Jamalludin. 2018. Analisis Faktor-Faktor Yang Mempengaruhi Produksi Usahatani Sayur-Sayuran Di Kelurahan Maharatu Kecamatan Marpoyan Damai Kota Pekanbaru. Jurnal Agribisnis. Vol. 20 (1): 52 - 67

Lingga, P., dan Edi Marsono. 2007. Petunjuk Penggunaan Pupuk. Edisi Kedua. Penebar Swadaya, Jakarta. 223 hal.

Mamondol, R.M. 2017. Efisiensi Penggunaan Faktor Produksi Tenaga Kerja Dan Modal Pada Usahatani Kedelai Di Kelurahan Pamona Kecamatan Pamona Puselemba Kabupaten Poso. Jurnal ENVIRA. Vol. 2 (2): $1-7$.

Muin, M. 2017. Pengaruh Faktor Produksi Terhadap Hasil Produksi Merica Di Desa Era Baru Kecamatan Tellulimpoe Kabupaten Sinjai. Jurnal Economix. Vol. 5 (1): 203 - 214.

Ningsih, I.M, Dwiastuti R., dan Suhartini, 2015. Determinan Efisiensi Teknis Usahatani Kedelai. Jurnal Manajemen dan Agribisnis. Vol. 12 (3): 216 - 225.

Tahir, A.G., Dedi H. Darwanto, J. Hadi Mulyo. 2010. Analisis Efisiensi Produksi Sistem Usahatani Kedelai di Sulawesi Selatan. Jurnal Agro Ekonomi. Vol. 28 (2) : 133 - 151.

Triyono, A., Purwanto,. dan Budiyono.2013. Efisiensi Penggunaan Pupuk N Untuk Pengurangan Kehilangan Nitrat pada Lahan Pertanian. Prosiding Seminar Nasional Pengelolaan Sumber Daya Alam dan Lingkungan 2013. ISBN 978-6002-179001-1-2: 526 - 531.

Yuliana., Ekowati T. Handayani M. 2017. Efisiensi Alokasi Penggunaan Faktor Produksi Pada Usahatani Padi di Kecamatan Wirosari Kabupaten Grobogan. Agraris: Jounal of Agribusiness and Rural Development Research. Vol. 3 (1): 40 - 47.

Zulkarnain, I. 2010. Aplikasi Pestisida dan Analisa Residu Pestisida Golongan Organoposfat Pada Beras di Kecamatan Portibi Kabupaten Padang Lawas Utara. [Skripsi]. Fakultas Kesehatan Masyarakat Universitas Sumatera Utara, Medan. 